\title{
Effects of a Customized Professionalism Educational Intervention on Physical Therapists' Knowledge and Attributes of Professionalism
}

Joseph A. Balogun Distinguished University Professor

Chicago State University, jbalogun@csu.edu

Chidozie E. Mbada Dr.

Obafemi Awolowo University, Ile-Ife, Nigeria, doziembada@yahoo.com

Adetutu O. Balogun Dr.

Brown Mackie College, Indiana, USA, adetutubalogun@aol.com

Udoka A. Okafor Dr.

University of Lagos, Nigeria, udochris@yahoo.com

Follow this and additional works at: https://nsuworks.nova.edu/ijahsp

Part of the Rehabilitation and Therapy Commons

\section{Recommended Citation}

Balogun JA, Mbada CE, Balogun AO, Okafor UA. Effects of a Customized Professionalism Educational Intervention on Physical Therapists' Knowledge and Attributes of Professionalism. The Internet Journal of Allied Health Sciences and Practice. 2018 Jan 01;16(2), Article 9.

This Manuscript is brought to you for free and open access by the College of Health Care Sciences at NSUWorks. It has been accepted for inclusion in Internet Journal of Allied Health Sciences and Practice by an authorized editor of NSUWorks. For more information, please contact nsuworks@nova.edu. 


\title{
Effects of a Customized Professionalism Educational Intervention on Physical Therapists' Knowledge and Attributes of Professionalism
}

\begin{abstract}
Purpose: There is a growing call around the world to include professionalism in the entry-level education of physical therapists and to teach professionalism as a continuing education professional development workshop for practicing physical therapists. Unfortunately, there is currently no empirical evidence to support the use of didactic instruction to effectuate a change in the knowledge and attributes of professionalism. This study evaluated the effects of a customized professionalism educational intervention on physical therapists' knowledge and attributes of professionalism.

Methods: A quasi-experimental research was conducted among 47 Nigerian physical therapists (Mean age $=41 \pm 10.1$ years). The educational intervention consisted of a 3-hour classroom lecture and five case studies on professionalism. The impact of the intervention was evaluated by a Professionalism Inventory that assesses the level of knowledge and attributes of professionalism - clinical competence, a spirit of inquiry, accountability, autonomy, advocacy, innovation and visionary, collegiality and collaboration, and ethics and value.

Results: Post intervention, the physical therapist's aggregate knowledge of professionalism score improved significantly from $69 \%$ to $77 \%$ performance level $(t=2.340 ; p<0.05)$. On the contrary, there was no significant difference in the aggregate attributes of professionalism score following the intervention $(t=1.396, p>0.05)$. Although the improvement observed in the aggregate attributes of professionalism score was not statistically significant, when the effects of the intervention were examined on the attributes of professionalism subscales, the results revealed that clinical competence, accountability, autonomy, innovation and visionary, and collaborating and collegiality improved significantly $(p<0.05)$. The intervention was of small practical significance (Cohen $d=.34$ and .20 for knowledge and attributes of professionalism scores, respectively).

Conclusions: It was inferred from the findings that a three-hour classroom instruction consisting of lectures and case studies presentation could improve the knowledge of professionalism of practicing physical therapists. A longer instructional period vis-à-vis mentoring and role modelling in the classroom may be needed to effectuate a practical change in professionalism.
\end{abstract}

Author Bio(s)

Joseph A. Balogun, PT, PhD, FACSM, FNSP, FAS, FRSPH, is a Distinguished University Professor in the Department of Health Studies, College of Health Sciences, Chicago State University, U.S.A; jbalogun@csu.edu

Chidozie E. Mbada, PT, PhD, is a Senior Lecturer in the Department of Medical Rehabilitation, Obafemi Awolowo University, Ile-Ife, Nigeria; doziembada@yahoo.com.

Adetutu O. Balogun, OTR/L, M Ed., OTD, is an Adjunct Professor in the Occupational Therapy Assistant Program at Brown Mackie College, Indiana, USA; adetutubalogun@aol.com

Udoka A. Okafor, PT, PhD, is a Senior Lecturer in the Physiotherapy Department, College of Medicine, University of Lagos, Nigeria; udochris@yahoo.com.

\section{Acknowledgements}

We are grateful to the physiotherapists who assisted with data collection in this study - Mr. Ojetola Kayode, Mrs. Olabisi Akinwande, Mr. John Omole, and Mr. Emmanuel Fashote, Drs. Taofeek Awotidebe and Olumide 
Dada

This manuscript is available in Internet Journal of Allied Health Sciences and Practice: https://nsuworks.nova.edu/ijahsp/vol16/iss2/9 


\title{
TIAHSP \\ The Internet Joưnal of Allied Health Sciences and Practice
}

Dedicated to allied health professional practice and education

Vol. 16 No. 2 ISSN 1540-580X

\section{Effects of a Customized Professionalism Educational Intervention on Physical Therapists' Knowledge and Attributes of Professionalism}

\author{
Joseph A. Balogun, PT, PhD, FACSM, FNSP, FAS, FRSPH ${ }^{1}$ \\ Chidozie E. Mbada, PT, PhD2 \\ Adetutu O. Balogun, OTR/L, M Ed., OTD 3 \\ Udoka A. Okafor, $\mathrm{PT}, \mathrm{PhD}^{4}$ \\ 1. Chicago State University \\ 2. Obafemi Awolowo University \\ 3. Brown Mackie College \\ 4. University of Lagos \\ United States/Nigeria
}

\begin{abstract}
Purpose: There is a growing call around the world to include professionalism in the entry-level education of physical therapists and to teach professionalism as a continuing education professional development workshop for practicing physical therapists. Unfortunately, currently, there is no empirical evidence to support the use of didactic instruction to effectuate a change in the knowledge and attributes of professionalism. We evaluated the effects of a customized professionalism educational intervention on physical therapists' knowledge and attributes of professionalism. Methods: A quasi-experimental study was conducted among 47 Nigerian physical therapists (Mean age $=41 \pm 10.1$ years). The educational intervention consisted of a three-hour classroom lecture and 5 case studies on professionalism. The impact of the intervention was evaluated by a Professionalism Inventory that assessed the level of knowledge and attributes of professionalism: clinical competence, a spirit of inquiry, accountability, autonomy, advocacy, innovation and vision, collegiality and collaboration, and ethics and value. Results: Post intervention, the physical therapists' aggregate knowledge of professionalism score improved significantly from $69 \%$ to $77 \%$ performance level ( $t=2.340 ; p$ $<.05)$. On the contrary, there was no significant difference in the aggregate attributes of professionalism score following the intervention $(t=1.396, p>$.05). Although the improvement observed in the aggregate attributes of professionalism score was not statistically significant, when the effects of the intervention were examined for the attributes of professionalism subscales, the results indicated that clinical competence, accountability, autonomy, innovation and vision, and collaborating and collegiality improved significantly $(p<.05)$. The intervention was of small practical significance (Cohen's $d=0.34,0.20$ for knowledge and attributes of professionalism scores, respectively). Conclusions: It was inferred from the findings that a three-hour classroom instruction consisting of lectures and case studies presentation could improve the knowledge of professionalism of practicing physical therapists. A longer instructional period vis-à-vis mentoring and role modelling in the classroom may be needed to effectuate a practical change in professionalism.

\section{INTRODUCTION}

Professionalism has been a core subject in medicine and allied health professions for many years. ${ }^{1-5}$ In physical therapy, professionalism continues to be a relevant issue as the knowledge base of the profession is still controvertible, and in many countries around the world, direct access and autonomous practice are still evolving. ${ }^{6}$ Over the years, medical and allied health professions have been skeptical in using attributes of professionalism for admission purpose, tracking professional student development, or for judging work performance of practitioners., ${ }^{2,7}$ This skepticism is due in part to the fact that professionalism is difficult to measure. It is kaleidoscopic and does change over time, particularly with clinical experience and as the practitioners can discern actions that incorporate behaviors and attributes of professionalism. 2,4 In this study, professionalism was defined as the consistent demonstration of behaviors that exemplify clinical competence, innovation and vision, a spirit of inquiry, ethics and
\end{abstract}


value, accountability, collegiality, and collaboration with the other members of the health care team to achieve optimal health and wellness in individuals and communities. ${ }^{5}$

There have been praiseworthy statements made by eminent physical therapists in the past that may readily lend physical therapy the face and façade of a true profession. For example, a former president of the American Physical Therapy Association (APTA), Ben Massey, opined in 2002 that "as a profession, we have arrived. We have defined our scope of practice. We have developed a unique body of knowledge. We are documenting the effectiveness of our outcomes. We adhere to a code of ethics. And we take responsibility for the well-being of patients and clients. True autonomy is the destination." 8 Many positive changes have occurred in physical therapy education and practice since Massey's presidential speech of 2002. In the United States, the profession has transitioned its entry-level education to a doctoral level, and direct access has become a reality. 9,10 As of January 1, 2015, all 50 states, the District of Columbia, and the US Virgin Islands now allow patients to seek several levels of treatment from a physical therapist without a prescription or referral from a physician. ${ }^{9}$ These recent development towards a true professional status in the United States (direct access, entry-level doctoral education, evidence-based practice) are a rarity in other parts of the world. Entrylevel education in physical therapy in most countries, both in developed and developing nations, are still at the baccalaureate or master's degree levels. ${ }^{11}$ A 2011 survey of 93 countries who are members of the World Confederation of Physical Therapists (WCPT) indicated that direct access to physical therapy services is allowed in $59 \%$ of WCPT member nations, and physical therapists are educated for independent practice in $63 \%$ of the countries. The baccalaureate (BS) degree is the most common entry-level education for physical therapists globally. More than $50 \%$ of WCPT member nations offer an entry-level BS degree. ${ }^{11}$ However, in recent years, there is a trend in several countries around the world to transition their entry-level education to a clinical doctor of physical therapy (DPT) degree. ${ }^{12-18}$

Considering the influence of globalization in health care, the professionalization of physical therapy across political and geographical boundaries will require a conceptual framework "to organize content related to physical therapy as a profession, the professional roles of physical therapists, and their development as professionals." 19 West and Shanafelt argued that to effectively promote professionalism, an appreciation of the personal and environmental factors that influence professional development is necessary. ${ }^{20}$ Professional core values are intertwined with the humanistic dimensions of professionalism, which are the art of physical therapy rather than the science. ${ }^{4}$ Cruess and Cruess and Nabishah et al speculated that the learning environment plays a vital role in the development of the fundamental elements of professionalism and that a collaborative learning environment rather than the competitive environment is essential in promoting educational development and the attributes of professionalism. ${ }^{21,22}$

Educational interventions in the form of classroom lectures, conferences, and short- and long-term continuing education professional development workshop have been used previously to improve job satisfaction, critical-thinking skills, and leadership and communication skills of physicians, nurses, and teachers. ${ }^{23-32}$ For example, a 20-day professional development course designed for primary school teachers demonstrated significant effects on the teachers' thinking, classroom practice in all subjects, and sense of professionalism. ${ }^{31}$ Also, a continuing education professional development workshop has been reported to improve leadership and communication skills of medical students and nurses. ${ }^{28-30}$

There is a growing call around the world to include professionalism contents in the entry-level physical therapy education curriculum and to offer professionalism-focused continuing education workshops for practicing physical therapists. ${ }^{15,16}$ Generic abilities, small group discussion, and related reading assignments are the 3 preferred teaching methods used by physical therapist educators to foster entry-level students' professionalism. ${ }^{33}$

Educators from various disciplines have advocated using lectures, case studies, mentoring, and role modeling in the classroom and clinical settings to advance the fundamental elements of professionalism. ${ }^{1,2,5,7} \mathrm{~A}$ search of the literature with the Cumulative Index to Nursing and Allied Health Literature (CINAHL) database, the most widely-used literature search engine by nursing and allied health professionals around the world, using the keywords professionalism, physical therapy, and intervention yielded 11 "hits." Only 3 of the 11 studies had addressed the effects of a planned educational intervention for core values development in physical therapy. ${ }^{34-36}$ There is currently a paucity of evidence in the literature to support the effectiveness of classroom lecture to change the core professionalism behaviors of physical therapists.

This study was used to evaluate the impact of a three-hour, professionalism-focused, continuing education workshop on the knowledge and attributes of professionalism of physical therapists. It was hypothesized that a customized didactic instruction for professionalism would enhance the skills and core values of the physical therapists. The terms attributes of professionalism, fundamental elements of professionalism, and core values of professionalism addressed the same social construct of professional behavior and were, therefore, used interchangeably in this paper.4,5,37

(C) The Internet Journal of Allied Health Sciences and Practice, 2018 


\section{METHODS}

\section{Ethics Approval}

The Institutional Review Board of the College of Medicine, University of Lagos, Nigeria, approved the protocol for this investigation (Application 05-08-15).

\section{Research Design and Study Participants}

A repeated measure pretest-posttest quasi-experimental design was employed to answer the research questions being investigated. The study was conducted during the 55th annual conference of the Nigeria Society of Physiotherapy held at Lokoja in October 2015. Registration for the study took place on the first day of the conference.

The participants who enrolled in the study were members of the Nigeria Society of Physiotherapy, gainfully employed at public and private hospitals and clinics throughout Nigeria. A total of 58 physical therapists initially registered for the study, and 47 (81\%) completed the posttest evaluation. Consequently, the data of 11 participants were not included in the statistical analysis due to incomplete information required.

During the registration for the study, informed consent from the physical therapists was obtained. The Professionalism Inventory evaluation tool was administered before the professionalism educational intervention lecture and was re-administered 1 hour after the lecture. Different colored papers (black ink print for pretest and blue ink print) were used to identify pretest-posttest responses while the date of birth matching was used for pairing the pretest-posttest responses of each participating physical therapist during data entry and analysis.

\section{Customized Professionalism Intervention}

The professionalism educational intervention implemented in this study consisted of two parts: lecture and discussion (case studies) components. The lecture was presented by the principal investigator who is a distinguished university professor with over 30 years of physical therapy administrative and teaching experience in various universities around the world. The content of the lecture was developed by the principal investigator from different sources in the literature. ${ }^{37,38}$ The highlights of the lecture are presented in Appendix 1.

The two-hour classroom lecture was followed by a one-hour question-and-answer session and presentation of case studies on professionalism. ${ }^{38}$ The 5 case studies about professionalism were adapted from the literature. The case studies are presented in Appendix 2. The co-investigators actively participated as "facilitators" in the discussion of the case studies. They were also responsible for administering the Professional Inventory before and after the workshop. The principal investigator met the study participants for the first time on the day of the workshop. Two of the 3 co-investigators knew many of the study participants. The educational intervention covered all the professional knowledge questions asked in the Professionalism Inventory.

\section{Outcome Measures}

The educational intervention was evaluated using a standardized Professionalism Inventory that has been found among Nigerian physical therapists to be highly stable and internally consistent when re- administered within two-week testing intervals. ${ }^{39}$ The Professionalism Inventory has 3 scales. The demographic scale had 2 open-ended questions (the date of birth and number of years of clinical experience) and 6 other questions about demographic information: gender, marital status, highest education, place of employment, clinical practice area, and practice setting. The knowledge of professionalism scale has 10 questions designed to assess respondents' basic understanding of professionalism. Each question has a Yes, No, or Don't know response option. The attributes of the professionalism scale has respondents rate their opinions on 16 professional behaviors and attitudes on a fivepoint Likert scale ranging in a continuum from Strongly Disagree (1) to Strongly Agree (5). The 16 attributes of professionalism, perception-based statements have 8 subscales: clinical competence, a spirit of inquiry, accountability, autonomy, advocacy, innovation and vision, collegiality and collaboration, and ethics and value. For knowledge of professionalism, the minimum score is 0 , and the maximum possible score is 100 ; the attribute of professionalism minimum score is 16 , and the maximum possible score is 80 .

\section{Statistical Analysis}

Statistical Package for Social Sciences (SPSS) software version 16 was used to analyze the data. The responses from the 8 demographic questions, 10 knowledge of professionalism questions, and 16 attributes of professionalism perception-based statements were coded into the computer. Before data analysis, the 5 possible responses for the attributes of professionalism perception-based statement were collapsed into 3 options: Agree, Neutral, and Disagree. Similarly, the knowledge of professionalism questions with 3 possible options was coded as True, False, and Don't Know. Raw data were cross-checked for accuracy before statistical analysis. Descriptive and inferential statistical procedures were computed to summarize the data. Both

(C) The Internet Journal of Allied Health Sciences and Practice, 2018 
the pretest-posttest knowledge and attributes of professionalism ratio data were mesokurtically (normally) distributed based on the result of the Shapiro Wilk test. Levene's test also indicated equal variance in the ratio data set. Consequently, we used the parametric paired t test to compare the pretest-posttest knowledge and attributes of professionalism subscale scores. A chi-square $\left(\mathrm{X}^{2}\right)$ nonparametric test was used to compare the nominal level individual pretest-posttest knowledge of professionalism questions and the individual attributes of professionalism perception-based statements. Alpha level was set at $p<.05$.

\section{RESULTS}

Table 1. Demographic Characteristics of the Study Participants $(N=47)$

\begin{tabular}{|c|c|c|c|c|}
\hline Question \# & 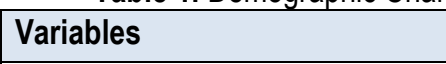 & Mean $( \pm S D)$ & Frequency & Percentage \\
\hline \multirow[t]{3}{*}{1} & Gender & & & \\
\hline & Male & & 45 & 78 \\
\hline & Female & & 13 & 22 \\
\hline \multirow[t]{4}{*}{2} & Marital Status & & & \\
\hline & Single & & 18 & 31 \\
\hline & Married & & 40 & 69 \\
\hline & Separated (Divorced) & & 0 & 0 \\
\hline \multirow[t]{4}{*}{3} & Age (years) & $41 \pm 10.1$ & & \\
\hline & $\leq 30$ & & 8 & 14 \\
\hline & $31-40$ & & 16 & 28 \\
\hline & $>40$ & & 34 & 58 \\
\hline \multirow[t]{4}{*}{4} & Educational Qualification & & & \\
\hline & Bachelor's & & 33 & 57 \\
\hline & Master's & & 13 & 22 \\
\hline & Doctorate & & 12 & 21 \\
\hline \multirow[t]{4}{*}{5} & Work Setting & & & \\
\hline & State/Federal government & & 39 & 68 \\
\hline & Private establishment & & 2 & 3 \\
\hline & Teaching/Specialist hospital & & 17 & 29 \\
\hline \multirow[t]{3}{*}{6} & Area of Practice & & & \\
\hline & Academia & & 6 & 10 \\
\hline & Clinical & & 52 & 90 \\
\hline \multirow[t]{6}{*}{7} & Years of Experience (years) & $15 \pm 9.8$ & & \\
\hline & $\leq 5$ & & 12 & 21 \\
\hline & $6-10$ & & 13 & 22 \\
\hline & $11-15$ & & 4 & 7 \\
\hline & $16-20$ & & 14 & 24 \\
\hline & $>20$ & & 15 & 26 \\
\hline \multirow[t]{4}{*}{8} & Practice Setting & & & \\
\hline & Orthopedics/Sports & & 27 & 47 \\
\hline & Pediatrics & & 4 & 6 \\
\hline & Neurology & & 27 & 47 \\
\hline
\end{tabular}


The majority of the physical therapists were males $(78 \%)$, older than 40 years of age $(59 \%)$, married $(69 \%)$, bachelor's degree holders (57\%), and individuals employed in a state/federal government establishment (67\%). Similarly, the majority of the physical therapists were the clinicians $(90 \%)$, with greater than 20 years of professional work experience $(26 \%)$, and employed in orthopedic/sports and neurology practice settings (47\%).

\section{Impact of Intervention on Professionalism Knowledge and Attributes of Professionalism}

As showed in Figure 1, post intervention, the physical therapist's aggregate knowledge of professionalism score improved significantly $(t=2.340, p<.05)$. Contrary to the stated hypothesis, there was no significant difference $(t=1.396, p>.05)$ in the aggregate attributes of professionalism score following the intervention.

Figure 1. Pretest-Posttest of Knowledge and Attributes Scores

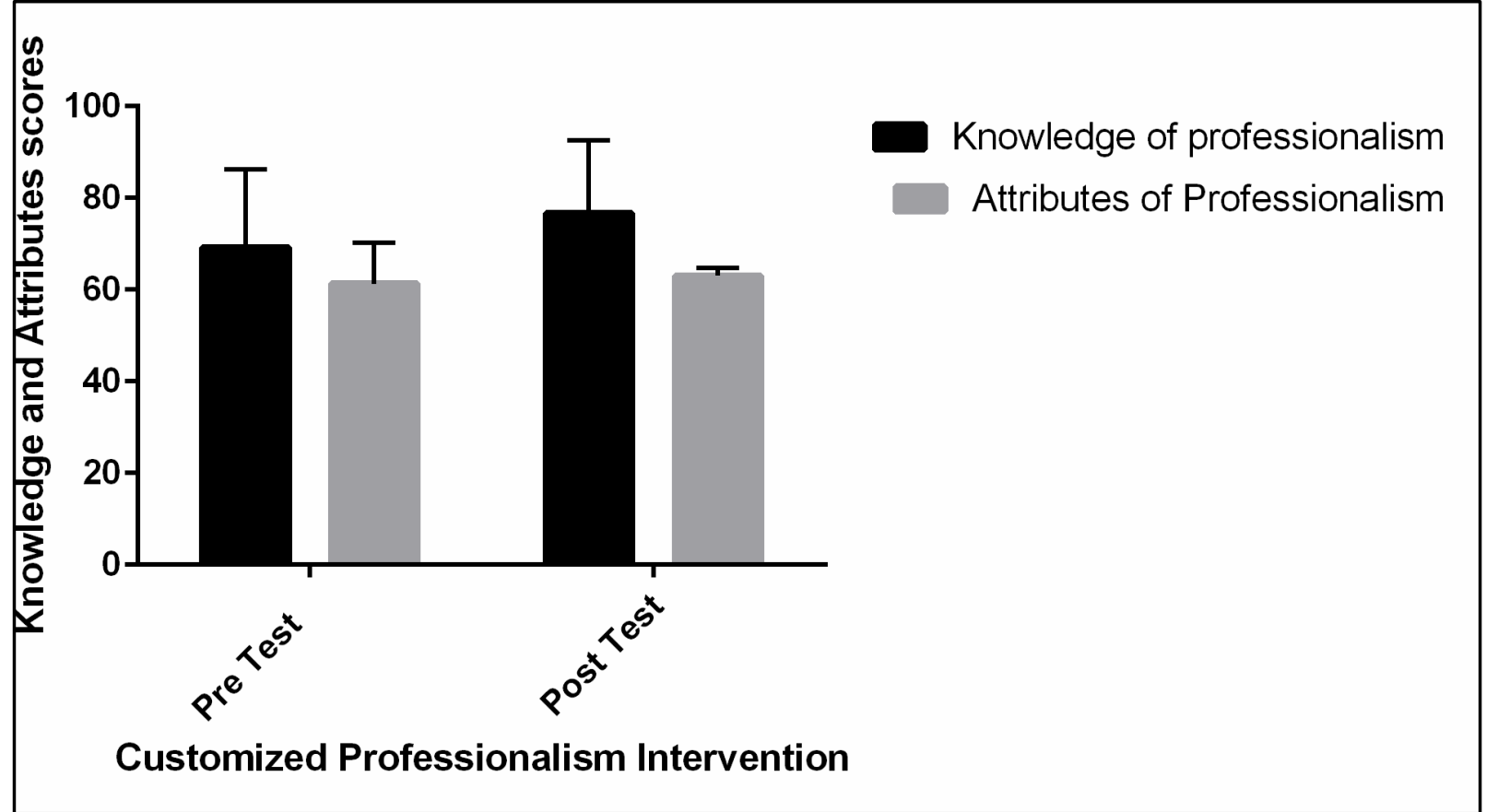

The educational intervention did not significantly $(p>.05)$ improve the aggregate attributes of professionalism score. However, an in-depth analysis of the professionalism subscales data indicated that the intervention score significantly $(p<.05)$ improved some attributes of professionalism. Clinical competence, accountability, autonomy, innovation and vision, and collaborating and collegiality improved significantly $(p<.05)$ while the spirit of inquiry, advocacy and ethics, and values remain unchanged by the educational intervention. 
Table 2. The Effects of the Educational Intervention on Aggregate Knowledge of Professionalism and the Individual Attributes of Professionalism Scores $(N=47)$

\begin{tabular}{|l|c|c|c|c|}
\hline \multicolumn{1}{|c|}{ Measures of professionalism } & $\begin{array}{c}\text { Impact of } \\
\text { Prean }(\mathbf{\pm S D})\end{array}$ & $\begin{array}{c}\text { Professionalism } \\
\text { Posttest } \\
\text { Mean }(\mathbf{\pm S D})\end{array}$ & $\begin{array}{c}\text { Focused } \\
\text { Paired } \boldsymbol{t} \text { test }\end{array}$ & $\begin{array}{c}\text { CEPDW } \\
\text { p value* }\end{array}$ \\
\hline Knowledge of professionalism & & & & \\
\hline $\begin{array}{l}\text { Aggregate knowledge of } \\
\text { professionalism score (\%) }\end{array}$ & $69 \pm 17.1$ & $77 \pm 15.9$ & 2.340 & $.024^{*}$ \\
\hline Attributes of professionalism subscales & & & & \\
\hline Clinical Competence & $3.9 \pm 0.39$ & $4.0 \pm 0.09$ & 2.233 & $.029^{*}$ \\
\hline Spirit of inquiry & $3.9 \pm 0.37$ & $4.0 \pm 0.09$ & 1.589 & .117 \\
\hline Accountability & $3.9 \pm 0.38$ & $4.0 \pm 0.09$ & 2.202 & $.032^{*}$ \\
\hline Autonomy & $3.7 \pm 0.53$ & $3.8 \pm 0.33$ & 2.513 & $.015^{*}$ \\
\hline Advocacy & $3.9 \pm 0.34$ & $3.9 \pm 0.15$ & 1.062 & .293 \\
\hline Innovation and vision & $3.7 \pm 0.60$ & $4.0 \pm 0.11$ & 3.091 & $.003^{*}$ \\
\hline Collaboration and collegiality & $3.9 \pm 0.41$ & $4.0 \pm 0.12$ & 2.088 & $.041^{*}$ \\
\hline Ethics and values & $3.9 \pm 0.33$ & $4.0 \pm 0.09$ & 1.698 & .095 \\
\hline $\begin{array}{l}\text { Aggregate attributes of } \\
\text { professionalism score }\end{array}$ & $61 \pm 9.03$ & $63 \pm 1.69$ & 1.396 & .176 \\
\hline
\end{tabular}

${ }^{*}$ Indicates significant difference $(p<.05)$ in the pretest-posttest scores

**The minimum score is 16 and the maximum possible score is 80 . CEPDW = Continuing education professional development workshop

The result of the chi-square test used to evaluate the effects of the educational intervention on knowledge of professionalism is presented in Table 3.

Table 3. The Impact of the Educational Intervention on the Individual Knowledge of Professionalism Questions ( $N=47)$

\begin{tabular}{|c|c|c|c|c|c|c|c|c|}
\hline \multirow[t]{2}{*}{ Q\# } & \multirow[t]{2}{*}{$\begin{array}{c}\text { Knowledge of professionalism } \\
\text { questions }\end{array}$} & \multirow[t]{2}{*}{$\begin{array}{l}\text { Prel } \\
\text { Post }\end{array}$} & True & False & $\begin{array}{l}\text { Don't } \\
\text { know }\end{array}$ & \multirow[t]{2}{*}{$x^{2}$} & \multirow[t]{2}{*}{$\begin{array}{c}p \\
\text { value }\end{array}$} & \multirow[t]{2}{*}{$\begin{array}{r}\text { Correct } \\
\text { response }\end{array}$} \\
\hline & & & $\%$ & $\%$ & $\%$ & & & \\
\hline \multirow[t]{2}{*}{9} & \multirow{2}{*}{$\begin{array}{l}\text { Professionalism is exclusively about } \\
\text { knowledge and } \\
\text { competence }\end{array}$} & Pre & 60.3 & 39.7 & 0 & \multirow[t]{2}{*}{16.503} & \multirow[t]{2}{*}{.001} & \multirow[t]{2}{*}{ False } \\
\hline & & Post & 60.3 & 36.2 & 3.4 & & & \\
\hline \multirow[t]{2}{*}{10} & \multirow{2}{*}{$\begin{array}{l}\text { Occupational status is the ordered } \\
\text { ranking to which the public or peer } \\
\text { professional } \\
\text { groups confer on a particular } \\
\text { occupation. }\end{array}$} & Pre & 91.4 & 5.2 & 3.4 & \multirow[t]{2}{*}{1.933} & \multirow[t]{2}{*}{.748} & \multirow[t]{2}{*}{ True } \\
\hline & & Post & 81.0 & \begin{tabular}{l|l|}
12.1 \\
\end{tabular} & 6.9 & & & \\
\hline \multirow[t]{2}{*}{11} & \multirow{2}{*}{$\begin{array}{l}\text { Occupational esteem is the regard in } \\
\text { which an occupation is being held by } \\
\text { the general public by virtue of its } \\
\text { power and other qualities, such as } \\
\text { altruism, competence, and } \\
\text { financial worth. }\end{array}$} & Pre & 89.7 & 8.6 & 1.7 & \multirow[t]{2}{*}{0.498} & \multirow[t]{2}{*}{.780} & \multirow[t]{2}{*}{ True } \\
\hline & & Post & 93.1 & 6.9 & 0 & & & \\
\hline \multirow[t]{2}{*}{12} & \multirow{2}{*}{$\begin{array}{l}\text { A semi-profession has esteem and } \\
\text { political power and is often } \\
\text { associated with sound specialized } \\
\text { educational } \\
\text { training. }\end{array}$} & Pre & 25.9 & 56.9 & 17.2 & \multirow[t]{2}{*}{14.934} & \multirow[t]{2}{*}{.005} & \multirow[t]{2}{*}{ False } \\
\hline & & Post & 20.7 & 75.9 & 3.4 & & & \\
\hline
\end{tabular}




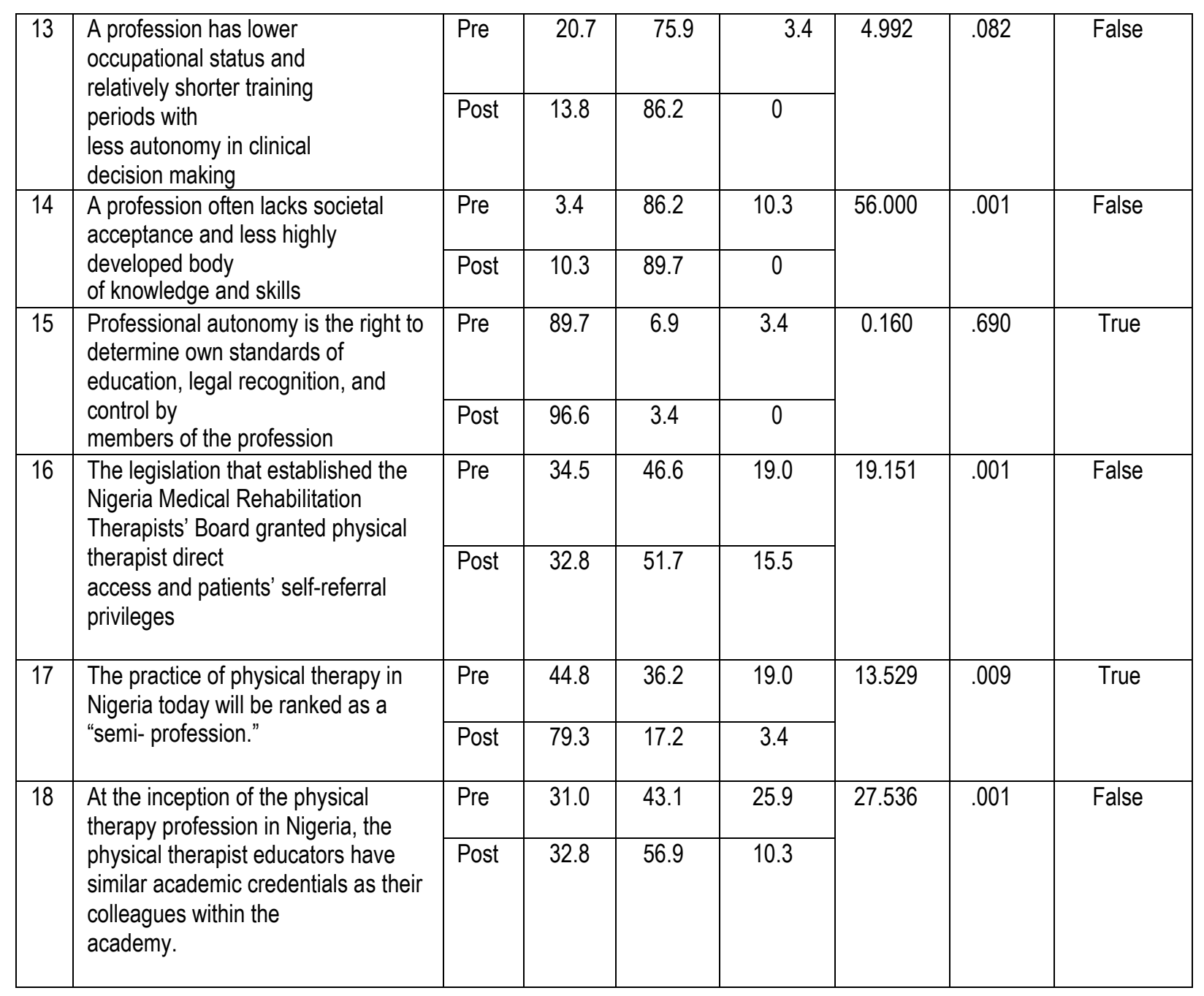

The Chi-Square test indicated significant $(p<.05)$ improvement in several of the knowledge of professionalism questions. Specifically, responses on 6 (issues \# 9,12,14,16,17, and 18) out of the 10 knowledge of professionalism questions were significantly $(p<.05)$ affected by the educational intervention. Table 4 presents the chi-square test used to evaluate the effects of the educational intervention on the attributes of professionalism. 
Table 4. The Impact of the Educational Intervention on the Individual Attributes of Professionalism Perception-Based Statements $(N=47)$

\begin{tabular}{|c|c|c|c|c|c|c|c|}
\hline \multirow{3}{*}{ Q\# } & \multirow{3}{*}{$\begin{array}{l}\text { Attributes of professionalism } \\
\text { perception-based statements }\end{array}$} & \multirow{3}{*}{$\begin{array}{l}\text { Pre I } \\
\text { Post }\end{array}$} & \multirow{3}{*}{\begin{tabular}{|c|} 
Agree \\
$\%$ \\
\end{tabular}} & \multirow{3}{*}{$\begin{array}{c}\text { Neutral } \\
\%\end{array}$} & \multirow{3}{*}{$\begin{array}{c}\text { Disagree } \\
\%\end{array}$} & \multirow{3}{*}{$x^{2}$} & \multirow{3}{*}{$p$ value } \\
\hline & & & & & & & \\
\hline & & & & & & & \\
\hline \multirow[t]{2}{*}{19} & \multirow{2}{*}{$\begin{array}{l}\text { I have physical therapy knowledge that is } \\
\text { both theoretical and clinical based }\end{array}$} & Pre & 95 & 0 & 5 & 0.209 & .648 \\
\hline & & Post & 97 & 0 & 3 & & \\
\hline \multirow[t]{2}{*}{20} & \multirow{2}{*}{$\begin{array}{l}\text { I use evidence-based knowledge in my } \\
\text { academic/clinical practice }\end{array}$} & Pre & 85 & 13 & 2 & 9.757 & .008 \\
\hline & & Post & 100 & 0 & 0 & & \\
\hline \multirow[t]{2}{*}{21} & \multirow{2}{*}{$\begin{array}{l}\text { I am open minded and have the desire } \\
\text { to explore new knowledge }\end{array}$} & Pre & 95 & 3 & 2 & 3.080 & .214 \\
\hline & & Post & 100 & 0 & 0 & & \\
\hline \multirow[t]{2}{*}{22} & \multirow[t]{2}{*}{ I am committed to life-long learning } & Pre & 95 & 3 & 2 & 3.080 & .214 \\
\hline & & Post & 100 & 0 & 0 & & \\
\hline \multirow[t]{2}{*}{23} & \multirow{2}{*}{$\begin{array}{l}\text { I work with both clients and } \\
\text { families to achieve desired } \\
\text { outcomes }\end{array}$} & Pre & 94.8 & 3.5 & 1.7 & 5.047 & .080 \\
\hline & & Post & 100.0 & 0.0 & 0.0 & & \\
\hline \multirow[t]{2}{*}{24} & \multirow{2}{*}{$\begin{array}{l}\text { I recognize my capabilities, } \\
\text { knowledge base and areas for } \\
\text { development }\end{array}$} & Pre & 91 & 7 & 2 & 5.225 & .073 \\
\hline & & Post & 100 & 0 & 0 & & \\
\hline \multirow[t]{2}{*}{25} & \multirow{2}{*}{$\begin{array}{l}\text { I work independently and engage } \\
\text { in decision making within the scope of } \\
\text { physical therapy practice }\end{array}$} & Pre & 79 & 12 & 9 & 1.096 & .578 \\
\hline & & Post & 86 & 7 & 7 & & \\
\hline \multirow[t]{2}{*}{26} & \multirow{2}{*}{$\begin{array}{l}\text { I am aware of the barriers that interfere } \\
\text { with my autonomy and I } \\
\text { am seeking ways to address the situation }\end{array}$} & Pre & 69 & 24 & 5 & 4.798 & .091 \\
\hline & & Post & 84 & 16 & 0 & & \\
\hline \multirow[t]{2}{*}{27} & \multirow{2}{*}{$\begin{array}{l}\text { I understand the patient's } \\
\text { perspectives }\end{array}$} & Pre & 95 & 3 & 2 & 1.009 & .604 \\
\hline & & Post & 97 & 3 & 0 & & \\
\hline \multirow[t]{2}{*}{28} & \multirow[t]{2}{*}{ I assist patients with their learning needs } & Pre & 90 & 10 & 0 & 0.438 & .508 \\
\hline & & Post & 93 & 7 & 0 & & \\
\hline 29 & I promote a culture of innovation to & Pre & 88 & 12 & 0 & 0.000 & .999 \\
\hline & enhance patient/family outcomes & Post & 88 & 12 & 0 & & \\
\hline 30 & I show initiatives for new ideas & Pre & 91 & 7 & 2 & 1.749 & .417 \\
\hline & & Post & 97 & 3 & 0 & & \\
\hline 31 & I collaborate with other professionals & Pre & 95 & 3 & 2 & 3.080 & .214 \\
\hline & & Post & 100 & 0 & 0 & & \\
\hline 32 & I mentor students and junior & Pre & 85 & 10 & 5 & 3.643 & .162 \\
\hline & $\begin{array}{l}\text { colleagues to enhance their } \\
\text { professional growth }\end{array}$ & Post & 93 & 7 & 0) & & \\
\hline 33 & I am knowledgeable about ethical values, & Pre & 93 & 7 & 0 & 1.881 & .170 \\
\hline & concepts and decision- making & Post & 100 & 0 & 0 & & \\
\hline 34 & I am able to identify ethical concerns, & Pre & 90 & 10 & 0 & 2.148 & .143 \\
\hline & issues and dilemmas in clinical practice & Post & 97 & 3 & 0 & & \\
\hline
\end{tabular}


The result of the chi-square test indicated that only one question (\# 20) out of the 16 attributes of professionalism perception-based statement was significantly $\left(X^{2}=9.757, p<.01\right)$ altered following the educational intervention (Table 4).

When the study participants were asked (open question \#35) to discuss what the Nigeria Society of Physiotherapy can do to transition the profession forward to the next level of excellence, the responses obtained were illuminating. The responses were examined qualitatively using the process of content analysis to categorize and identify principle themes. The major issues identified by the physiotherapists included continuing education and professional development; political engagement and participation of members in mainstream politics; commencement of clinical residency training program; legal support and increased role in hospital and training accreditation; sanctions and certification by the Medical Rehabilitation Therapists' Board of Nigeria; stoppage of diploma in physical therapy and detrimental acts, such as quackery and non-payment of association dues; clinically relevant research; scholarships and fellowships; improve internal cohesion and unity; and engagement in advocacy and image making (rebranding).

\section{DISCUSSION}

In this study, we set out to investigate the effect of a three-hour customized professionalism focused continuing education professional development workshop on the knowledge and attributes of professionalism of physical therapists.

The findings in this study in part were supported by the stated research hypothesis. The result showed significant improvement in the physical therapists' aggregate knowledge of professionalism from $69 \%$ before the educational intervention to $77 \%$ performance post intervention. Paradoxically, the physical therapists' total attributes of professionalism remain unchanged after the educational intervention. From this finding we implied that the attributes of professionalism are a complex and multidimensional social construct that is not readily amenable to change by a short classroom instruction. A longer didactic interaction between the instructor and the learners may likely have resulted in the desired improvement in the attributes of professionalism. A longer instructional period vis-à-vis mentoring and role modeling in the classroom and clinical settings may be needed to effectuate a change in the core values of professionalism. ${ }^{25,29-31}$

The physical therapists in this study demonstrated "poor" knowledge of professionalism as the average baseline (pre-intervention) score for knowledge of professionalism was only $69 \%$. This finding is not particularly surprising because professionalism is not currently taught in the physical therapy education programs in Nigeria. Previous studies have demonstrated that the personality of lecturers has a strong effect on the behavior and attitude of the students towards developing the humanistic elements of professionalism. ${ }^{40-41}$ It is also now generally recognized that a non-threatening collaborative learning environment plays a critical role in promoting the development of the core elements of professionalism. ${ }^{21,22}$ With the assumption that the ideas and values of physical therapy profession will be conveyed by mentors and role models, it is reasonable to speculate that mentoring and role modeling in a supportive clinical environment will effectuate a positive change in the fundamental elements of professionalism which are the unique aspects of humanism.

The overall results of this study among practicing physical therapists in Nigeria are consistent with the findings in the 3 previous studies in which the impact of planned educational interventions on the core values development of physical therapist students in the United States were evaluated. ${ }^{34-36}$ Hayward and Blackner examined the effect of an international service-learning experience on cultural competence and the 7 core values that underpin the professional skills required by the doctor of physical therapy students using the Professionalism Physical Therapy Core Values (PPTCV) psychometric instrument. ${ }^{34}$ The students' aggregate and subscale PPTCV scores, accountability, altruism, compassion, excellence, integrity, professional duty and social responsibility, improved significantly $(p<.05)$ following the service learning course.

In another study, Hayward and Charrette evaluated the impact of a 360-assessment (standardized patients) method designed to teach and assess the core values development of doctor of physical therapy students. ${ }^{35}$ Standardized patients were defined in the study as a simulation learning pedagogy method used in medical and physical therapy education in which lay persons are trained to mimic a patient condition and provide realistic teaching experiences for students and opportunity for faculty to evaluate the skill acquisition of the students. Following the innovative standardized patients teaching strategy, the students $(\mathrm{N}=84)$ aggregate PPTCV scores improved significantly $(p<.01)$ immediately post intervention, but decreased significantly $(p<.01)$ after an eightweek clinical education experience.

Anderson and Irwin evaluated a program for ${ }^{36}$ entry-level physical therapist students (11 male and 32 female, ages 20 to 28 years) who completed the PPTCV self-assessment survey after their first three- week clinical experience and again after their final clinical experience. ${ }^{36}$ The aggregate and subscale PPTCV scores increased significantly $(p<.05)$ after 33 weeks compared with scores

(c) The Internet Journal of Allied Health Sciences and Practice, 2018 
after 3 weeks of clinical education. Female students' aggregate PPTCV scores were significantly $(p<.05)$ higher than the male scores on both the first and second time frame self-assessments. Also, female students' scores on accountability, excellence, integrity, and professional duty were significantly higher than their male counterparts. Anderson and Irwin concluded that the improvement observed in the PPTCV scores indicate that their physical therapy education program is playing an important role in the development of professional behavior, knowledge, and application in practice. ${ }^{36}$

In addition to the acquisition of cognitive knowledge and mastery of clinical skills, the profession of physical therapy requires high standards of behavior that encompass the core values of professionalism. Unfortunately, professionalism is one of the curricular hidden and best-kept secrets that is "caught rather than taught." ${ }^{4}$ However, things are changing for the better because the importance of formally teaching professionalism is now widely accepted, and it is now gradually incorporated into the undergraduate curriculum of medical and allied health professions in several countries around the world. 1,2,4,21-27,33,36 Al-Sudani and associates argued that "high-profile role modeling, lectures, seminars, and academic ceremonies are ways of achieving professional development among dental students in parallel with their acquisition of basic scientific knowledge and clinical skills." ${ }^{41}$ They posited that this approach would formally and informally communicate that professionalism is critical in the professional socialization process.

The recognition of physical therapy as a "doctoring" profession in the United States alongside other advancements in direct access and evidence-based practice has recently stimulated interests about the concepts of individual and collective professionalism in physical therapy. There is the expectation that physical therapist educators would develop effective methods to teach and assess the professional behavior of their entry-level and post-professional students. ${ }^{33}$ The availability of customized educational instructions, such as the one implemented in this study, will facilitate the teaching of professionalism as a continuing education professional development workshop for practicing physical therapists. When asked to discuss what the Nigeria Society of Physiotherapy can do to bring the profession to the next level of excellence, the study participants overwhelmingly asserted that entry-level doctoral education will provide a satisfying pathway to accelerate the professionalization of physical therapy in Nigeria. Physical therapy education in Nigeria is currently in transition from entry level to doctor of physical therapy program. The Nigeria Society of Physiotherapy is awaiting the approval of the proposal that was submitted to the National University Commission for curriculum change in the 12 universities offering physical therapy program in Nigeria.

\section{Practical Significance of the Intervention}

The Cohen's $d$ value was computed to assess the practical significance of our intervention. A Cohen's $d$ value with an effect size of .8 is considered a "large" practical significance, .5 is of "moderate" practical significance, and .20 is considered a "small" practical significance..$^{43}$ For the aggregate knowledge of professionalism and aggregate attributes of professionalism scores, we obtained Cohen's d effect size values of .34 and .20 , respectively. These values are within the range of "small" practical significance..$^{43} \mathrm{~A}$ longer instructional period vis-à-vis mentoring and role modeling in the classroom and clinical settings will be needed to effectuate a "large" practical change in professionalism.

\section{Limitations and Future Research}

This study has some limitations that should be considered in interpreting the results. The study design was a quasi-experimental (pretest-posttest) research protocol without random assignment of study participants into groups. Furthermore, there was no control group in the study design. The absence of a control group in the experimental design indicates that the improvement observed in professionalism knowledge may be attributed in part to the "learning effect." To strengthen the external validity of the findings, follow-up studies should re-administer the research instrument at different time frames (such as 6 months and 1 year) to assess plausible carryover of the knowledge acquired from the educational intervention. Another limitation of this study is the short duration of the educational intervention. A significant change in attitude and behavior cannot be expected after a three-hour lecture and case studies presented on professionalism.

The majority (86\%) of the sample in this study were adults older than 30 years with an average of 15 years clinical experience as physical therapists. The results of this study may not be externally valid for young and recent physical therapy graduates. The study participants were a sample of convenience not randomly selected from the register of the Nigeria Society of Physiotherapy or the Medical Rehabilitation Therapy Licensing Board of Nigeria. Therefore, caution should be exercised in generalizing the results of this study to all physical therapists in Nigeria because there could be regional differences, given the diversity in culture and socio-demographic characteristics of the physical therapists in the different parts of the country. ${ }^{44}$ Given these limitations, a causeand-effect inference cannot be drawn from the results of this study. Future studies should utilize a true experimental design that will include randomization of subjects into experimental and control groups before the educational intervention.

(c) The Internet Journal of Allied Health Sciences and Practice, 2018 


\section{CONCLUSION}

The physical therapists in this study demonstrated "poor" knowledge of professionalism. This finding has implications for curricula and national licensure policy reforms in physical therapy in Nigeria. It was inferred from the findings of this study that a three-hour classroom instruction consisting of lectures and case studies presentation can improve the knowledge of professionalism of practicing physical therapists. A short professional development workshop on professionalism can be beneficial for practicing physiotherapists.

\section{REFERENCES}

1. Robins LS, Braddock CH 3rd, Fryer-Edwards KA. Using the American Board of Internal Medicine's "elements of professionalism" for undergraduate ethics education. Acad Med. 2002 Jun;77(6):523-31. [PMID: 12063196]

2. Arnold L. Assessing professional behavior: yesterday, today, and tomorrow. Acad Med. 2002;77(6):502-14. [PMID: 12063194]

3. Vicarelli G, Spina E. Professionalization and Professionalism: The case of Italian dentistry. P \& P. 2015;5(3):1-16.

4. Salam A, Song CO, Mazlan NF, Hass H, Lee LS, Abdullah MH. Professionalism of future medical professionals in Universiti Kebangsaan Malaysia (UKM) Medical Centre. Int Med J. 2012;(3):224-9.

5. Fantahun A, Demessie A, Gebrekirstos K, Zemene A, Yetayeh G. A cross sectional study on factors influencing professionalism in nursing among nurses in Mekelle Public Hospitals, North Ethiopia, 2012. BMC Nurs. 2014;13(1):10. doi: 10.1186/1472-6955-13-10. [PMID: 24708544]

6. WCPT launches new infographics profiling the profession globally. Available from: www.wcpt.org/news/Infographicsprofile-profession-May15 ; http://www.wcpt.org/node/100179 http://www.wcpt.org/policy/ps-autonomy. Accessed: January 31, 2017.

7. Cahalin LP. The Linda Crane lecture professionalism and core values in physical therapy: lessons learned from Linda Crane. Cardiopulm Phys Ther J. 2012;23(2):30-9. [PMID: 22833707]

8. Massey BF Jr. APTA presidential address: What's all the fuss about direct access? Phys Ther. 2002;82:1120-3. [PMID: 12405876]

9. American Physical Therapy Association (APTA). Direct Access at the State Level. Available from: http://www.apta.org/Statelssues/DirectAccess/ Jun 29, 2016. Accessed: November 23, 2016.

10. Commission on Accreditation in Physical Therapy Education. Aggregate Program Data. American Physical Therapy Association. 2016. Available from: http://www.capteonline.org/uploadedFiles/CAPTEorg/About_CAPTE/Resources/Aggregate_Prog ram_Data/AggregateProgramData_PTPrograms.pdf. Accessed: November 23, 2016.

11. World Confederation for Physical Therapy (WCPT). 2016; Available from: http://www.wcpt.org/education/Entry-levelphysical-therapy-education-programmes. Accessed: November 23, 2016.

12. Nicholson SK. The Evolution of Physical Therapy in the USA. In Nicholson SK. The Physical Therapist's Business Practice and Legal Guide. Jones \& Bartlett. 2015; Chapter 1:1-37.

13. Moffat M. A History of Physical Therapist Education around the World.Available from: https://www.questia.com/library/journal/1P3-2592212731/a-history-of-physical- therapist-education-around-the Accessed: January 20, 2018.

14. John EB, Pfalzer LA, Fry D, Glickman L, Masaaki S, et al. Establishing and upgrading physical therapist education in developing countries: Four case examples of service by Japan and United States physical therapist programs to Nigeria, Suriname, Mongolia, and Jordan. JOPTE. 2012;26:29-39.

15. Footer CB, Tsegaye HS, Yitnagashaw TA, Mekonnen W, Shiferaw TD, et al. Empowering the physiotherapy profession in Ethiopia through leadership development within the doctoring process. Front Public Health. 2017;5:51. [PMID: 28377916]

16. Belay MM, Wamisho BL, Gebre SA. Doctor of physiotherapy program in Ethiopia. Asian J Sci Tech. 2017;8(1);415460.

17. Plack MM. The evolution of the doctorate of physical therapy: Moving beyond the controversy, 2015. Available from: URL: http://citeseerx.ist.psu.edu/viewdoc/download?doi=10.1.1.457.9158\&rep=rep1\&type=pdf Accessed: January 20, 2018.

18. Balogun JA, Oyeyemi A, Balogun AO. Entry-level doctor of physiotherapy in Nigeria: Program readiness evaluation. Int J Curr Res. 2017;9(7):54884-91.

19. Swisher LL, Paige CG. Professionalism in Physical Therapy: History, Practice, Development. Elsevier, 2005.

20. West CP, Shanafelt TD. Physician well-being and professionalism. Minn Med. 2007;90(8):44-6. [PMID: 17899849]

(c) The Internet Journal of Allied Health Sciences and Practice, 2018 
21. Cruess SR, Cruess RL. Teaching professionalism- why, what and how. Facts Views Vis Obgyn. 2012;4(4):259-65. [PMID: 24753918]

22. Nabishah M, Farihah HS, Das S, Salam A, Siti Marium B, et al. Problem based learning facilitation: challenges to higher education educators. Int Med J. 2009;16(4):243-6.

23. Ludmerer KM. Instilling professionalism in medical education. JAMA. 1999;282(9):881-2. [PMID: 10478696]

24. Epstein RM, Hundert EM. Defining and assessing professional competence. JAMA. 2002;287(2):226-35. [PMID: 11779266]

25. Goodall J, Day C, Lindsay G, Muijs D, Harris A. Evaluating the Impact of Continuing Professional Development (CPD). Research Report. Department of education and skill. University of Warwick. 2005. Available from: http://www.nationalarchives.gov.uk/webarchive/ Accessed November 23, 2016.

26. Ludmerer KM, Johns MME. Reforming graduate medical education. JAMA. 2005;294:1083-7. [PMID: 16145029 ]

27. Wilson I, Cowin LS, Johnson M, Young H. Professional identity in medical students: pedagogical challenges to medical education. Teach Learn Med. 2013;25(4):369-73. [PMID: 24112208]

28. Berg D, Sebastian J, Heudebert G. Development, implementation and evaluation of an advanced physical diagnosis course for senior medical students. Acad Med. 1994;69(9):758-64. [PMID: 8074777]

29. Begat IB, Severinsson El, Berggren IB. Implementation of clinical supervision in a medical department: nurses' views of the effects. J Clin Nurs. 1997;6(5):389-94. [PMID: 9355473]

30. Hyrkas K. Clinical supervision, burnout, and job satisfaction among mental health and psychiatric nurses in Finland. Issues Ment Health Nurs. 2005;26(5):531-56. [PMID: 16020067]

31. Turner-Bisset R, Nichol J. A sense of professionalism: the impact of 20-day courses in subject knowledge on the professional development of teachers. Teacher Dev. 1998;23:433-55. doi:1080/13664539800200057

32. Karimi M. The effects of professional development initiatives on EFL teachers' degree of self-efficacy. Aust J Teacher Educ. 2011;36(6):50-62.

33. Davis DS. Teaching professionalism: a survey of physical therapy educators. J Allied Health. 2009;38(2):74-80. [PMID: 19623788]

34. Hayward LM, Blackmer B. A model for teaching and assessing core values development in doctor of physical therapy students. JOPTE. 2010;28(3):16-25.

35. Hayward LM, Charrette AL. Integrating cultural competence and core values: an international service-learning model. JOPTE. 2012;26(1):78-89.

36. Anderson DK, Irwin KE. Self-assessment of professionalism in physical therapy education. Work. 2013;44(3):275-81. [PMID: 23324679]

37. Health and Care Professions Council: Professionalism in Healthcare Professionals. 2014. Available from: http://www.hpc- uk.org/assets/documents/10003771Professionalisminhealthcareprofessionals.pdf. Accessed: January 20, 2018.

38. National Center for Ethics in Health. Professionalism in Patient Care. Integrated Ethics: Improving Ethics Quality in Health care: VA Health care. 2013. Available from: Department of Veterans Affairs, Veterans Health Administration, Washington, DC 20420.

39. Balogun JA, Mbada CE, Balogun AO, Okafor UAC. Development and evaluation of the readability, stability and internal consistency of a psychometric instrument designed to assess physiotherapists' knowledge and attributes of professionalism. Int J Med Health Sci Res. 2017;4(6):102-17. doi:10.18488/journal.9.2017.46.102.117.

40. Haghdoost AA, Shakibi MR. Medical students and academic staff perceptions of role models: an analytical cross sectional study. BMC Med Educ. 2006;6:9. [PMID: 16503974]

41. Al-Sudani D, Al-Abbas F, Al-Bannawi Z, Al-Ramadhanb A. Professional attitudes and behaviors acquired during undergraduate education in the College of Dentistry, King Saud University. Saudi Dent J. 2013;25(2):69-74. doi: 10.1016/j.sdentj.2013.02.003. [PMID: 23960558]

42. Gillespie M. Student teacher connection in clinical nursing education. J Adv Nurs. 2002;37(6):566-76. [PMID: 11879421]

43. Cohen J. Statistical Power Analysis for the Behavioral Sciences, 2e. 1988. Hillsdale, NJ: Lawrence Earlbaum.

44. Balogun JA, Mbada C, Balogun AO, Okafor U. Nigerian physiotherapists' knowledge and attributes of professionalism. Cogent Med. 2017;4:4:1382181. doi.org/10.1080/2331205X.2017.1382181 
Appendix 1. Highlights of the Lecture Presentation

- What are the recognized obligations and values of a physical therapist?

- What are the roles of the physical therapist within the Nigerian health care system?

- What does it mean to be a member of a profession?

- What are the differences between an occupation and profession?

- Hierarchical importance of professions

- What is professionalism and what constitutes professionalism?

- With professionalism everything matters; from overall appearance to professional use of equipment

- Professionalism is about good behavior, positive attitude towards the job and respect for the other members of the healthcare team

- What are the differences between professionalism and professionalization?

- What are the differences between individual and collective professionalism?

- What are the elements/attributes of professionalism?

- Professional vs. unprofessional behaviors

- Lack of professionalism: Signs and symptoms

- Effects of professionalism on co-workers and patients

- Is professionalism compatible with the restrictions sometimes placed on physiotherapist's judgments in private practice environment?

- History of physical therapy profession in Nigeria

- Professionalization milestones of physical therapy education globally

- The veritable path to true-professional status in physical therapy in Nigeria.

- How to measure professionalism (peer evaluation, patient survey, staff evaluation, self- assessment using professional portfolios, standardized inventories) APTA, Professionalism Mini Evaluate Exercise (The PMExp), Balogun's Professionalism Inventory

- How to teach professionalism: role modeling, bedside teaching, simulated patient scenarios, and small group discussions

- Differences between minor vs. major clinical lapses and critical clinical events 


\section{Appendix 2. Case Studies}

\section{Case Study \#1}

Mr. Ukpo, a retired school teacher, came to your department for outpatient physical therapy after hip replacement surgery. As his physiotherapists, you have been trying to arrange transportation home for him but have been unsuccessful. Staffing within your department is tight, but because Mr. Jackson is very upset about the prospect of missing his son's birthday ceremony at home, you are considering driving him home yourself. What should you do?

\section{Case Study \#2}

Mr. Mohammad had a right lobectomy and was referred to you for postoperative physical therapy. During your inpatient visit, the patient developed an unexpected tachycardia that requires advanced cardiac life support, including CPR, for approximately one minute. Would you discuss with Mr. Mohammad the untoward event that occurred when you meet with him the following day?

\section{Case Study \#3}

Because of his religious views, one of the physiotherapists in your department, Chioma, refuses to treat patients who are openly gay. As the head of department, how would you handle this development in your department?

\section{Case Study \#4}

Mr. Adegoke is an 84-year-old obese man with low back pain and 65 years history of heavy tobacco smoking. He was referred for physical therapy. His chest X-ray is consistent with metastatic lung cancer. Before you had a chance to examine Mr. Adegoke, you are approached by his eldest son, who says that to honor the patient's cultural traditions, you should make all treatment decisions in consultation with the family (instead of the patient). Because their father had a grave cancer diagnosis, they do not want him to be told as this would destroy his will to live. What should you do?

\section{Case Study \#5}

You are a physiotherapist employed in an outpatient orthopedic clinic. An orthopedic surgeon who sometimes works in your clinic is known for his sudden and unpredictable outbursts of anger. When something goes wrong, he often reacts by raising his voice and intimidating other staff. You recently witnessed an episode in which he yelled at your colleague, "You must be even stupider than I thought!" Your partner ran off in tears. What should you do?

Adapted from National Center for Ethics in Health (2013). Professionalism in Patient Care. IntegratedEthics: Improving Ethics Quality in Health care: VA Health Care. 